JOURNAL OF PUBLIC HEALTH FOR TROPICAL AND COASTAL REGION

(JPHTCR)

Journal homepage: http:/ejournal2.undip.ac.id/index.php/jphtr/index

ISSN : 2597-438

\title{
Analysis on Village Readiness in the Acceleration of Open Defecation Free Achievement Status Based on Stimulus, Organism, and Response Approach
}

\author{
Siti Farihah Rosanna*1, Khabib Fadlilatul Ma'ruf ${ }^{*}$, Yogi Aditya ${ }^{1}$, Globila Nurika ${ }^{1}$, \\ Edza Aria Wikurendra ${ }^{2}$ \\ ${ }^{1}$ Faculty of Public Health, University of Jember, Indonesia \\ ${ }^{2}$ Management and Organizational Science, Faculty of Economic Science, Hungarian University of \\ Agriculture and Life Science, Hungary \\ *Corresponding Author. Email: ocha80132@gmail.com
}

\begin{abstract}
Introduction: Open Defecation Free (ODF) is a condition in the community that has carried out total sanitation and do no more Open Defecation (OD). Dukuh Village was chosen as the research location because it was a village with the highest OD in Ngadiluwih, Kediri. This high rate of OD is caused by lack of public awareness about the importance of sanitation. This research was conducted to analyze the village readiness to accelerate ODF status in Dukuh Village.

Methods: This study was done in a qualitative method with a single holistic case study design using Stimulus-Organism-Response theory. The key informants of this study were five persons:1) the Head of Dukuh Village, 2) the environmental health officer of Wonorejo Community Health Center, 3) Dukuh Village community leader and 4) the community representatives who still defecated and 5) no more defecated in open area after triggering activities. They were selected purposively. Data were collected through in-depth interviews, Focus Group Discussion, and documents' review. Data analysis was done through Spradley model, scoring and categorizing village readiness using the scales of Aydin and Tasci.

Results: Five main problems were the lack of funds for ODF program, poor socialization, low Clean and Healthy Behavior, lack of roles from community leaders, and limited land for latrine construction. Based on the analysis of village readiness in achieving the ODF program using Aydin \& Tasci scale, the obtained score was 2.1. This score indicated that Dukuh Village was not ready yet and a lot of system improvements were needed.

Conclusion: Dukuh Village was not ready yet for ODF program and need a lot of system improvements. It was, recommended to make village policies, create working groups, and maximizing the socialization.
\end{abstract}

Keywords: Open Defecation, village, sanitation, behavior, community

Article History: Received: $15^{\text {th }}$ March 2021, Revised: $5^{\text {th }}$ August 2021, Accepted: $28^{\text {th }}$ August 2021

\section{Introduction}

Open Defecation (OD) behavior is the act of disposing of human feces in open areas such as rice fields, fields, bushes, rivers, beaches, forests, and other open areas which results in the contamination of the environment, soil, air, and water. OD behavior is one of the unhealthy behaviors because it will negatively impact health status, such as causing diarrhea, trachoma, worm infections, and stunting. ${ }^{1}$ About 892 million of the world's total population still 
practice defecation. ${ }^{2}$ This practice also occurs in some of the Indonesian society. Based on the 2018 Basic Health Research results, only $88.2 \%$ of Indonesians who defecated on latrines. ${ }^{3}$ This shows that some of Indonesian community still practiced OD, which can cause health problems.

The implementation of good sanitation is one of the bases for achieving optimal public health. ${ }^{4}$ The degree of public health is an indicator of program success through various continuous, integrated, and cross-sectoral efforts to implement development policies in the health sector. One of the actions that can be conducted to improve public health is Community-Led Total Sanitation (CLTS). Through the Ministry of Health of Republic of Indonesia, the government has launched CLTS Program to increase Clean and Healthy Behavior efforts. CLTS is an approach to increase hygiene and sanitation behavior through community empowerment and reducing morbidity and mortality due to poor sanitation. CLTS is an activity that focuses on integrated preventive and promotive efforts to trigger and maintain sustainable changes in communities' behavior to live clean and healthy. This communities then have an active role in providing their own basic sanitation by providing latrines. ${ }^{5}$

The CLTS program has five pillars as the basis for the strategy to achieve environmental health, namely Stop Open Defecation, Wash Hands with Soap, Processing of drinking water and household food, Management of Household Waste, and Treatment of Household Liquid Waste. Stop Open Defecation is the first pillar in implementing CLTS. This shows the importance of implementing ODF behavior in creating a healthy environment.

Open Defecation Free (ODF) is the condition of a community that has carried out total sanitation by not Open Defecation (OD). A village can be considered ODF if $100 \%$ of the villagers have access to defecate in healthy latrines. Based on the East Java Health Profile in 2020 , access to sanitation in East Java Province still reached $91.99 \%$. The villages that have reached ODF status were 4,940 villages
(58.13\%) out of 8,498 villages. ${ }^{6}$ Thus, it is necessary to implement ODF in all villages in East Java Province.

The ODF program's achievement requires community participation to understand the importance of implementing sanitation to improve community health status. Changing people's behavior into not defecate in the open area is not easy. It needs to be done continuously and sustainably based on the ODF program. ${ }^{7}$ Changing the behavior of defecating on the latrine needs to be done with an approach to the community to instill the awareness of the importance of maintaining environmental health. Increasing public awareness can be done by triggering the community against the dangers and risks arising from open defecation.

Only twelve districts/cities had already achieved ODF status in East Java Province in 2019. The rest of 26 districts/cities in East Java Province had not received ODF status, including Kediri Regency. Kediri Regency has 26 districts, 20 districts of them still have not achieved ODF status, one of them is Ngadiluwih District. In Kediri Regency, out of 344 villages, there were 222 villages or $64.5 \%$ which still had open defecation behavior. In Ngadiluwih District, there were eight villages that have not achieved ODF status. Dukuh Village is the village with the highest number of OD households (230 households) in Ngadiluwih District. ${ }^{8}$

Based on a preliminary study conducted in March 2021, data collected by in-depth interviews with informants were five people, including head of Dukuh village, community representatives $O D$ include triggering ODF program, environmental officer of Wonorejo Public Health Centers, and community leaders. The cause of the high number of $O D$ in Dukuh Village, Ngadiluwih District, Kediri Regency is due to the absence of a specific budget for the ODF program, inadequate socialization, low public awareness regarding Clean and Healthy Living Behavior, the role of less active social organizations, and limited land for making latrines in community homes. Therefore it is necessary to improve these problems and change people's behavior to care about the importance of implementing sanitation to 
improve health status. People still think that $O D$ in the river is more practical than in a toilet. This makes the ODF achievement in Dukuh Village even low and makes Dukuh Village the highest village in the case of OD in Ngadiluwih District.

The achievement of ODF in every village needs community participation by increasing awareness and changing people's behavior from OD to defecate in healthy latrines. Also, the village government's role as a policymaker and environmental officer in carrying out educational activities and providing stimulus to the community to change their behavior is crucial to increase latrine access and reduce the OD rate in Dukuh Village. Therefore, this research was conducted to analyze the village government's readiness to accelerate ODF status in Dukuh Village, Kediri Regency. The results can be used to formulate a policy recommendation to accelerate the achievement of ODF status in Dukuh Village, Kediri Regency.

\section{Methods}

Research design

This research was a qualitative study, with a single holistic case study design. This research was conducted using a modification to the theory StimulusOrganism-Response (SOR approach), to determine the research variables shown in Table 1. All involved variables and their definitions can be seen in Table 1.

Table 1. List of Variables and their Definitions

\begin{tabular}{|c|c|c|c|c|}
\hline Parameters & Variable & Variable definition & $\begin{array}{l}\text { Primary } \\
\text { Data }\end{array}$ & $\begin{array}{l}\text { Secondary } \\
\text { Data }\end{array}$ \\
\hline \multirow[t]{3}{*}{ STIMULUS } & $\mathrm{X} 1$ & $\begin{array}{l}\text { Triggering program carried out by the } \\
\text { health workers at Public Health Center } \\
\text { to encourage changes in individuals or } \\
\text { communities' hygiene behavior and } \\
\text { sanitation based on their own } \\
\text { awareness by touching the feelings, } \\
\text { thought pattern, behavior, and habits } \\
\text { of individuals or communities }\end{array}$ & Yes & No \\
\hline & $\mathrm{X} 2$ & $\begin{array}{l}\text { The existence of written and/or } \\
\text { unwritten village policies that have } \\
\text { been implemented to support the } \\
\text { implementation of ODF program }\end{array}$ & Yes & Yes \\
\hline & X3 & $\begin{array}{l}\text { ODF Program Funds owned by the } \\
\text { Village and or Public Health Center as } \\
\text { well as sponsorship activities from the } \\
\text { private sector to finance the } \\
\text { implementation of ODF program in the } \\
\text { village }\end{array}$ & Yes & No \\
\hline \multirow[t]{2}{*}{ ORGANISM } & $\mathrm{X} 4$ & $\begin{array}{l}\text { Role and support from the figures in } \\
\text { the village community to encourage } \\
\text { community behavior changes to } \\
\text { defecate only in healthy latrines after } \\
\text { triggering activities or the introduction } \\
\text { of ODF program in the village. }\end{array}$ & Yes & No \\
\hline & $\mathrm{X5}$ & $\begin{array}{l}\text { The existence of human resources and } \\
\text { infrastructure owned by the village to } \\
\text { support the implementation of ODF } \\
\text { program }\end{array}$ & Yes & Yes \\
\hline
\end{tabular}




\begin{tabular}{lllll}
\hline Parameters & Variable & Variable definition & $\begin{array}{l}\text { Primary } \\
\text { Data }\end{array}$ & $\begin{array}{l}\text { Secondary } \\
\text { Data }\end{array}$ \\
\hline RESPONSE & $\mathrm{X} 6$ & $\begin{array}{l}\text { The knowledge of individuals and the } \\
\text { majority of the community regarding } \\
\text { stopping OD behavior. }\end{array}$ & No \\
\cline { 2 - 5 } & X7 & $\begin{array}{l}\text { Attitudes of individuals and the majority } \\
\text { of society as indicated by evaluative } \\
\text { statements or community responses or } \\
\text { reactions in relation to stopping } \\
\text { defecation behavior after triggering } \\
\text { activities or the introduction of ODF } \\
\text { program in the village. }\end{array}$ & No \\
& $\begin{array}{l}\text { Individual and majority community } \\
\text { actions are shown in defecating only in } \\
\text { healthy latrines after triggering } \\
\text { activities or introducing the ODF } \\
\text { program in the village. }\end{array}$ & No \\
\cline { 2 - 5 } & &
\end{tabular}

Method of selection and informants

Purposive sampling technique was used for the selection of respondents in this study. This non-random sampling technique is used to identify and select unique, special, and specific cases that require in-depth investigation. This technique also support the aim of the study to form some recommendations for the village government. The key informants of this study were five persons i.e. 1) the Head of Dukuh Village, Ngadiluwih District, Kediri Regency as the policymakers at the Village level and implementers of local government programs to accelerate the Village ODF status, 2) the environmental health officer of Wonorejo Community Health Center, Ngadiluwih District as the executors of regional programs, 3) Dukuh Village community leader as the program recipients, who also the influencer of community behavior changes, and 4) the community representatives who still defecated and 5) no more defecated in open area after triggering activities. This research was conducted in Dukuh Village, Ngadiluwih District, Kediri Regency, and was carried out in March 2021.

\section{Data collection methods and instruments}

Primary data were collected by indepth interviews using structured questionnaires and Focus Group Discussion (FGD). Secondary data were collected by government documents' review using a checklist. The purpose of the in-depth interviews was to identify OD's causes, which include stimulus, organism, and response. The stimulus was the CLTS program by triggering latrine facilities, village policies to support the ODF program, and identifying the availability of specific funds to support the ODF program. The organism was from the community leaders, human resources, and village infrastructure in supporting the implementation of ODF program. Responses were the knowledge, attitudes, and actions individually and in most of the community after ODF program triggering activities. The process of in-depth interviews was carried out with the environmental Public Health Center, heads of Dukuh Village, community leaders, people who had received the ODF program's triggering, and people who were still doing OD. The FGD aimed to equalize perceptions and prioritize problems based on in-depth interviews to formulate alternative solutions with the community.

\section{Data analysis method}

Data analysis was done in three parameters: (i) stimulus, (ii) organism, and (iii) response. The three parameters consist of 8 indicators, which can be seen in Table 1. Primary data, which is qualitative data, were analyzed with Spradley model using Nvivo. Primary and secondary data were collected and scored. The scoring results were analyzed using Aydin and Tasci Scale to produce the level of readiness, which 
includes: (i) not ready, requires many system improvements, (ii) not ready, requires a little system improvement, (iii) ready; however, it needs some improvement in readiness, and (iv) it is ready to be continued. ${ }^{9}$ Table 2 shows the indicators for assessing village readiness in the village acceleration program for ODF

Table 2. Village Readiness Indicators

\begin{tabular}{lll}
\hline No & Dimensions & Indicator \\
\hline 1. & Funds & Allocation Budget \\
\cline { 3 - 3 } & & Community financial capacity \\
\hline 2. & Human Resources & Competencies \\
\cline { 3 - 3 } & & Training \\
\hline 3. & Infrastructure & Communal latrine \\
\cline { 3 - 3 } & & Materials and building tools \\
\hline 4. & $\begin{array}{l}\text { The role of village } \\
\text { community }\end{array}$ & Village community organizations \\
\cline { 3 - 3 } & & $\begin{array}{l}\text { Community leaders } \\
\text { Group Sanitation }\end{array}$ \\
\hline 5. & Organization & Policy \\
\cline { 3 - 3 } & & Triggering program \\
\hline
\end{tabular}

All of the subjects had received informed consent and agree to participate in this study. A certificate of ethical clearance has been received from the Ethics Commission for Health Research, Faculty of Dentistry, University of Jember with the number of 1177/UN25.8/KEPK/DL/2021.

\section{Results}

Kediri Regency has 26 districts, 344 villages, and 37 Public Health Center. Based on the report from the Environmental Health Section of Kediri Regency Health Office, efforts to prevent OD had been carried out, but there were still various problems such as the absence of specific ODF program funds, low socialization from Public Health Center and village government to the community, Lack of public awareness of Clean and Healthy Behavior, Lack of role community leaders, and limited land for the construction of latrines in the community homes. These were the reasons why OD cases were still occurring. The report from the Environmental Health Section of Kediri Regency Health Office regarding the development of ODF coverage in Dukuh Village, Ngadiluwih District, Kediri Regency in 2019-2020 can be seen in Table 3. Dukuh Village in 2020 has not been able to achieve ODF. The improvement of ODF, according to the informant, indicated that there was public awareness regarding defecation on the latrine. However, the awareness was not evenly distributed among all people in the village, thus ODF village has not reached yet. ODF village required that all village people have already defecated on healthy latrines. ${ }^{10}$

This statement of key informant (the Head of Dukuh Village), male, 38 years old and a high school graduate:

"sebenarnya dari 230 KK yang masih BABS itu bisa jadi malah lebih banyak soalnya kesadarannya memang masih rendah. Kalau air sungainya lagi banyak, malah mereka lebih memilih $B A B d i$ sungai" (informan 1, 38 tahun)

"In fact, there are more than 230 families who are still defecating openly because their awareness is still low. If the river water is more abundant, they prefer to defecate in the river" (informant 1, 38 years old)

Based on these statements, ODF village coverage was low, they were still a large number of households that practiced open defecation. The results of the in-depth interview showed that five problems occurred: (i) Ineffective socialization, (ii) limited funding sources, (iii) unavailability of land for making latrines in the community homes, (iv) lack of awareness of people's behavior to defecate on the latrine, and (v) 
Lack of community organizations who took a role in implementing ODF program. Five problems were obtained from the results of in-depth interviews, which were subsequently discussed in the FGD to dig deeper and find out the priority of these problems. Based on the FGD activity, priority results were obtained, and the causes of problems were as follows:

\section{a. Limited funds sources}

In-depth interviews with the Village Head showed that the problems regarding limited fund was the low economic status of the community and the absence of social assistance from the government for latrine construction. In Dukuh Village, the community still prioritized for the economic recovery due to the COVID-19 pandemic. This statement shows the as follows:

"sejauh ini pihak desa tidak ada sosialisasi atau himbauan dari pihak kecamatan terkait bantuan sosial untuk program Stop Buang Air Besar Sembarangan, dan sekarang masih fokus untuk pemberian bantuan korona" (informan 1, 38 tahun)

"So far, we hadn't received any socialization or appeal from the village regarding social assistance for the ODF program, and currently it is still focused on providing corona social assistance" (informant 1, 38 years old)

\section{b. Lack of Socialization}

Based on in-depth interviews with the informants, the ODF status was not achieved because the lack of socialization regarding ODF program. This program has not become a priority in the outreach carried out by health centers and villages. So far, the socialization of health programs still focused on efforts to improve maternal and child health.

This is as conveyed by the key informant as follows:

"Sudah ada mas sosialisasi kepada masyarakat tentang SBS, tapi ya gitu mas tidak maksimal, soalnya kebanyakan sosialisasi yang dilakukan itu untuk perbaikan gizi anak dan kesehatan ibu" (informant 1, 38 tahun)
There has been a socialization program to the public about ODF, but it is not optimal, because most of the socialization was for the improvement of child nutrition and maternal health. (informant 1, 38 years old)

The main informant who is male, 51 years old, and a high school graduate also conveyed the following:

"iya ada mas penyuluhannya, tapi terakhir tahun pas jamannya pak SBY" (informan 2, 51 tahun)

"Yes, there was information dissemination to the community, but it was about 5 years ago" (informant 2, 51 years old)

The additional informant said:

"sebenarnya sudah ada penyuluhan mas, tapi hanya beberapa kali karena kami masih fokus untuk peningkatan gizi ibu dan anak seperti yang dikatakan pak

kades" (informan 4, 47 tahun)

"Actually there has been some information dissemination to the community, but only a few times because we are still focused on improving the nutrition of mothers and children, as said by the village head" (informant 4, 47 years old )

\section{c. Shortage of defecation on latrine behavior}

The problem of shortage behavior of defecate on the latrine is caused by a lack of shame, disgust, knowledge, and community awareness in implementing healthy and clean behavior. The community believes that defecating in the river is more comfortable, practical, and cheaper than on a latrine because they still have to construct and maintain latrines, which cost a lot of money.

This is as conveyed by the main informant as follows:

"kulo biasane lek buang hajat ning kali mas, soale luwih enak ae. Gak perlu nyiram, hawane yo luwih enak pisan (bahasa jawa). Keluargaku biasane lek buang hajat kudu nyiapne kresek sek, 
terus di guak ning jamban utowo tempat sampah" (informan 3, 42 tahun )

"I usually defecate in the river, because it's more comfortable. I don't need water and the air circulation is cool. My family usually has to prepare a plastic bag, then throw it in the latrine or trash can" (informant 3, 42 years old )

Additional informants said:

"asline masyarakat iki ora nduwe kesadaran pisan gawe BAB ning jamban. Masyarakat juga masih banyak yang berpikir bahwa BAB di sungai lebih praktis dan nyaman" (informan 5, 51 tahun)

"In fact, the community has absolutely no awareness of defecating on the latrine.

They also think that defecating in the river is more practical and comfortable" (informant 5, 51 years old)

\section{d. Lack of community organization role Based on results in-depth} interviews with key informants, the community organizations such as the youth organization in Dukuh Village were not optimal in taking their roles due to the lack of communication with the village officials. Thus, many people did not know about the ODF program and they still practiced open defecation.

Additional informants said:

"asline masyarakat iki yo gak aktif golekgolek informasi" (informan 5, 51 tahun )

"actually people were not active in looking for information" (informant 5, 51 years old )

This is as conveyed by the key informant as follows:

"iya betul mas kata Pak Jamingan, masyarakat disini juga kurang aktif dan karang tarunanya tidak jalan. Jadi gak pernah ada informasi tentang program Stop Buang Air Besar Sembarangan kepada masyarakat" (informan 1, 38 tahun)
"Yes, that's true as Mr. Jamingan said, the people were less active and the youth organization doesn't work. So there was no information about ODF to the public" (informant 1, 38 years old)

\section{e. Lack of land for latrines in} community houses.

Based on in-depth interviews with key informants and additional informants, namely the village chief and community leaders, the problem was caused by a lack of land for latrine construction in their houses. To overcome this problem, village officials built communal latrines only in some parts of the neighborhood, so not all of the community benefited from the communal latrines.

This was as conveyed by the key informant as follows:

$$
\begin{gathered}
\text { "sebenarnya ada masyarakat yang mau } \\
\text { membangun jamban, tapi lahannya ini } \\
\text { yang gak ada. Jadi kami membantu } \\
\text { dengan membangunkan jamban komunal } \\
\text { untuk masyarakat meskipun masih } \\
\text { beberapa saja" (informan 1, } 38 \text { tahun) }
\end{gathered}
$$

"Actually, there are people who want to build latrines, but there is not enough land.

So we helped by building communal latrine even though there were only a few" (informant 1, 38 years old)

The additional informant said: "yo betul mas jare pak kades, omahe wong-wong podo mepet ning dalan gede lan tonggo liyone dadi kangelan lek mbangun jamban. Tapi masio wes dibantu desa gawe WC umum, masyarakat panggah buang hajate ning kali" (informan 5, 51 tahun)

"Yes, that's right as the village head said, people's houses are close to each other's houses and close to the main road, so it's difficult to build latrines. However, even though we has helped by building communal latrine, the community still defecates in the river" (informant 5, 51 years old)

Village Readiness Measurements with 'Aydin and Tasci Scale' 
In this study, a framework was developed to classify research components obtained from the previous research. The components investigated are:

1. Funds with the indicators of budget allocation and community financial capacity;

2. Human Resources with the indicators of competence and training;

3. Infrastructures with the indicators of communal latrine and materials \& tools building;

4. The Role of Village Community with the indicators of village community organizations, community leader, and

Sanitation Working Group;

5. Organization with the indicators of policy and triggering program.

Based on calculations using the scale of Aydin and Tasci, Dukuh village reached a score of 2.21 that showed that Dukuh village was not ready or needs a lot of system improvements to achieve ODF village status. Table 3 shows that each dimensions studied was still in an unprepared stage, thus a lot of system improvements are needed.

Table 3. Analysis of Village Readiness in Achieving ODF Village Status

\begin{tabular}{|c|c|c|c|}
\hline No & Dimension & Indicator & Results \\
\hline \multirow[t]{4}{*}{1.} & \multirow[t]{4}{*}{ Fund } & Budget Allocation & 2 \\
\hline & & Community financial capacity & 2 \\
\hline & & Total & 4 \\
\hline & & Outcome & 2 \\
\hline \multirow[t]{4}{*}{2.} & \multirow[t]{4}{*}{ Human Resource } & Competence & 3 \\
\hline & & Training & 1 \\
\hline & & Total & 4 \\
\hline & & Outcome & 2 \\
\hline \multirow[t]{4}{*}{3.} & \multirow[t]{4}{*}{ Infrastructure } & Communal latrine & 3 \\
\hline & & Materials \& tools Building & 4 \\
\hline & & Total & 7 \\
\hline & & Outcome & 3,5 \\
\hline \multirow[t]{5}{*}{4.} & \multirow[t]{5}{*}{ The Role of Village Community } & Village community organizations & 2 \\
\hline & & Community leader & 3 \\
\hline & & Sanitation Working Group & 1 \\
\hline & & Total & 6 \\
\hline & & Outcome & 2 \\
\hline \multirow[t]{4}{*}{5.} & \multirow[t]{4}{*}{ Organization } & Policy & 1 \\
\hline & & Triggering Program & 1 \\
\hline & & Total & 2 \\
\hline & & Outcome & 1 \\
\hline
\end{tabular}

Note:

(i) Not ready, needs a lot of improvement system (Score 1 - 2.59)

(ii) Not ready, needs a little improvement on the system (Score: 2.6 - 3.39)

(iii) ready, but needs some improvement in readiness (Score: $3.4-4.19$ ) )

(iv) ready to continue. (Score: 4.2 - 5)

\section{Discussion}

Many families in Dukuh Village, Ngadiluwih District, did not know about ODF program. This condition may lead to the 230 families to practice open defecation. The geographical conditions of
Dukuh Village also support this. Ngadiluwih District in Kediri Regency, is passed by a river so that it becomes a place for the people to practice OD. Besides, there were no land in their houses to build latrines with septic tanks and public latrine is far from the 
house. The strategy of Dukuh Village Head to decrease the high number of $O D$ in Dukuh Village is to build communal latrines, but they were only in a few places, due to the limited specific budget for this ODF program.

The first problem is related to the absence of a specific budget for implementing ODF program in Dukuh Village. This problem is one of the obstacles in accelerating the achievement of ODF villages. A study in Indonesia, showed that the village government needs to allocate a budget for ODF program activities to accelerate the achievement of ODF villages. ${ }^{11}$ The funds can be used to provide latrines for people who still do not have access to latrines and the construction of public toilets to overcome the limited land in the community house. Also, the funds can be used to implement the ODF program's triggering activities to increase public knowledge and accelerate community behavior changes.

The second problem is related to the low socialization of ODF program to the public. Socialization is used to provide information about the importance of implementing healthy and clean behavior, especially defecating on the latrine. The provision of information also needs to be balanced with triggering efforts by trained and certified facilitators so that the acceleration of ODF in Dukuh Village can run optimally. Based on the Regulation of the Minister of Health of the Republic of Indonesia Number 3 of 2014 concerning Community-Led Total Sanitation, implementing the CLTS program is necessary to trigger efforts in the community. Triggering efforts can be carried out by health workers, cadres, volunteers, and communities who have successfully implemented the CLTS program. The triggering efforts aimed to plan, monitor, and evaluate the results of behavior change. A study in Indonesia, showed that triggering program can accelerate the behavior change from open defecating to defecating on the latrine. ${ }^{12}$

The results of the FGD indicated that the community still practiced OD frequently even though they already had a latrine. This is due to the lack of public awareness of defecating on the latrine.
Socialization from health personnels that had been carried out only prioritizes the increasing knowledge. A study conducted in Bandung, explained that in the CLTS program, changing one's behavior could not be done by only pay attention to the knowledge. Because good knowledge did not necessarily follow by good attitudes and actions. ${ }^{13}$ Good attitudes and actions will arise when people become aware of the importance of defecating on the latrine. Besides, to increase motivation not to practice OD, it is necessary to create disgustion and shame in the community.

Based on the fourth problem, the obtained information, explain that the community's role is crucial, especially community organizations, in supporting the CLTS program. The role of community organizations is critical to disseminate information about the importance of making healthy latrines. This is consistent with the research results in 14 countries, explaining that many areas fail to build latrines in rural areas because local people did not value, use, or maintain the facilities. ${ }^{5}$

Based on the fifth problem, which is about the limited land for latrine construction in some community houses, it can be seen that land for latrine construction is very important in achieving CLTS program. In the poor and dense population, usually this problem occurs. The study conducted in Mozambique showed that more crowded the population, more difficult to build latrines. ${ }^{14}$

The analysis of village readiness shows that Dukuh Village is in the category of not ready or needs a lot of system repairs so that improvements are needed in all dimensions/variables. The variable of funds still needs improvement in allocating special funds for ODF program and selfhelp from the community. In the human resources variable, people with competence in sanitation are required, especially for ODF triggering program. Training for cadres is required to guide the community in monitoring and evaluating the program. In terms of infrastructure, communal latrines needed to be build more evenly in Dukuh Village. In the variable of village community roles, village community organizations' needs to be more active in participating on ODF program, such as 
becoming a bridge between the community and village officials, so that information synchronization occurs. In organizational variables, improvements are needed in written and unwritten regulations to become norms in the society and improvements in maximizing the information dissemination to the community to improve their knowledge, attitudes, and actions.

\section{Conclusion}

Priority problems in Dukuh Village are the lack of funds for ODF program, low socialization and public awareness on clean and health behaviors, the lack community leaders' roles and limited land for the construction of permanent healthy latrines. Based on the analysis of the village's readiness according to the theory of Analysis on the village readiness toward open defecation free status based on Aydin and Tasci scores concluded that Dukuh Village in the category is not ready and needs a lot of system improvements. Therefore, the recommendations given to Dukuh Village for accelerating the achievement of ODF Village status are: making written village regulations, create a working group and evaluating the implementation of ODF program, exploiting social assistance, maximize the information dissemination to increase knowledge and attitudes that include shame, disgust, guilty feeling when practice OD, and community actions to defecate on the latrine, reactivating social organizations such as youth organizations, Family Welfare Movement, and mosque youth in implementing CLTS program.

\section{Acknowledegment}

This acknowledgment are addressed to the community, Dukuh Village community leaders, Environmental Officers of Wonorejo Public Health Center, and Dukuh Village officials who have given permission and assisted in the study.

\section{Funding}

Self funding.

\section{Author Contribution}

Siti Farihah Rosanna: conceptualization, validation, data collection, data analysis, and, methodology.

Yogi Aditya: conceptualization, data collection, and data analysis

Khabib Fadlilatul Ma'ruf: conceptualization, data collection and data analysis.

Globila Nurika: writing-original, draft preparation, and writing-reviewing.

Edza Aria Wikurendra: draft preparation and writing-reviewing.

\section{References}

1. Alemu F, Kumie A, Medhin G, Gebre T, Godfrey P. A socioecological analysis of barriers to the adoption, sustainablity and consistent use of sanitation facilities in rural Ethiopia. BMC Public Health. 2017;17:1:1-9.

2. Aydin $\mathrm{CH}$, Tasci D. International Forum of Educational Technology \& Society Measuring Readiness for eLearning: Reflections from an Emerging Country. Journal of Educational Technology and Society. 2005;8:4:244-257.

3. Cameron L, Olivia S, Shah M. Scaling up sanitation: Evidence from an RCT in Indonesia. Journal of Development Economics. 2019;138:1-16.

4. Dinas Kesehatan Kab. Kediri. Profil Kesehatan Kabupaten Kediri Tahun 2019. Dinas Kesehatan Kabupaten Kediri. 2019:53-56.

5. Dinas Kesehatan Provinsi Jawa Timur. Profil Kesehatan Provinsi Jawa Timur. 2019:25-26.

6. Mosler HJ, Mosch S, Harter M. Is Community-Led Total Sanitation connected to the rebuilding of latrines? Quantitative evidence from Mozambique. PLoS ONE. 2018;13:5:1-16.

7. Odagiri $M$, Cronin AA, Thomas A, Kurniawan MA, Zainal M, Setiabudi W, et al. Achieving the Sustainable Development Goals for water and sanitation in Indonesia - Results from a five-year (2013-2017) largescale effectiveness evaluation. International Journal of Hygiene and Environmental Health. 
2020;230:113584.

8. Permenkes. Sanitasi Total Berbasis Masyarakat. Jakarta, Kementerian Kesehatan Republik Indonesia. 2014.

9. Riskesdas. Hasil Utama Riset Kesehata Dasar (RISKESDAS). 2018:1-200.

10. Routray P, Schmidt WP, Boisson S, Clasen T, Jenkins MW. Sociocultural and behavioural factors constraining latrine adoption in rural coastal Odisha: An exploratory qualitative study Global health. BMC Public Health. 2015;15:1.

11. Routray $P$, Torondel $B$, Jenkins MW, Clasen T, Schmidt WP. Processes and challenges of community mobilisation for latrine promotion under Nirmal Bharat Abhiyan in rural Odisha, India. BMC Public Health. 2017;17:1:1-15.
12. Saleem M, Burdett T, Heaslip V. Health and social impacts of open defecation on women: A systematic review. BMC Public Health. 2019;19:1.

13. Sari SYI, Setiadi AA, Sanjaya DK, Raksanagara AS. Community-Led Total Sanitation Program Attain to Increase Knowledge, Attitude and Intention but Fail to Change the Community's Behavior; Case Study in Urban Slum Area in Bandung Municipality. IOP Conference Series: Earth and Environmental Science. 2019;248:1.

14. Zuin V, Delaire C, Peletz R, CockEsteb A, Khush R, Albert J. Policy Diffusion in the Rural Sanitation Sector: Lessons from CommunityLed Total Sanitation (CLTS). World Development. 2019;124:104643. 